\title{
Category of Tenses of Verbs in the Azerbaijanian and Japanese Languages
}

\author{
Ogtay B. Jalilbayli ${ }^{1}$ \\ ${ }^{1}$ Baku State University, Azerbaijan \\ Correspondence: Ogtay B. Jalilbayli, Head of the Department of Far Eastern languages and literature, Faculty of \\ the Oriental studies, Baku State University, Azerbaijan. E-mail: ogtay_jalilbeyli@yahoo.com
}

Received: July 22, 2015 Accepted: August 15, 2015 Online Published: September 29, 2015

doi:10.5539/ijel.v5n5p136 URL: http://dx.doi.org/10.5539/ijel.v5n5p136

\begin{abstract}
The article explores tenses of verbs in the Azerbaijanian and Japanese languages on the basis of their comparison. Structural-semantic and functional features of verb tenses are described in the both compared languages. Morphological indications of verb tenses are thrown light on the basis of correlation of language and speech, mutual correlations of the elements of the lexical units. Syntactic position, in which different tenses of verbs in the investigated languages are used, is considered. Determination of real position of the meaning of the tenses possesses senses just in the parts where positions oppose one another in their differentiations in the points of count-down. Consequently, role of category of tenses shows itself in pointing out the one, in which relation at the moment of speech the phenomenon of reality stands, with which the contents of the given utterance are related. Also the correlation of tenses and voices, tenses and mood and so on, which possess more significance in the structure of the sentence are thrown light in the investigation.
\end{abstract}

Category of verb tenses is a complex grammatic category, which is expressed by steady morphological indications, appearing in conformity with objective laws of the language. Characteristic for the grammatical category of tenses in the both languages is the fact that it expresses both the relation of moment of speech with the moment of action (absolute meaning), and the relation with the moment with which another event is correlated (relative meaning) in the sentences and in the texts.

Study of a circle of tense meanings of the verbs in the compared languages makes it possible to determine common features for the Azerbaijani and Japanese languages and specific peculiarities for each of their categories of verb tenses.

Characteristic for the Azerbaijani language is the fact that the relative meaning acts as one of the meanings of some tense forms of the verb. If a relative meaning is expressed by the morphological indications, then the difference between absolute and relative meanings is discovered on the morphological level, on the level of pluskvamperfect of future in the past tense. Relative meaning of the tense forms of verbs may depend on the contextual environment. In this case difference between absolute and relative tenses lies on the level of syntactic tenses.

System of tenses of verbs in the Japanese language is different by the fact that one and the same form of the verb is able to express several different meanings. Depending on the context of the form of verb in the Japanese language acquire relatively-tense meanings. It gives us ground to qualify the system of tense forms of verbs in the Japanese language as absolutely-relative.

In the Japanese language temporal opposition of the language makes it possible to unite several grammatical meanings and their various shades of meanings in one form of the verb. Verb forms with the meaning of absolute tense forms can be used for the expression of the meanings of absolute tenses, i.e. they in certain positions and in certain contexts acquire relatively-temporal meanings.

In the Japanese language in the speech referring to the past, the predicate of the main sentence acquires form of non previous tenses, if the actions expressed by these tenses on a certain space of time take place parallelly with the actions expressed by the predicate of the following sentence. Often, on the basis of temporal relations of speech in the past is understood a certain moment or the space of time about which it is spoken. In this case, all the actions finishing till this moment appear by the forms of previous tense, and the rest by the non-previous forms. The actions, 
which are not completed, can't be considered as the mentioning of the action of the previous one and is expressed by the verb form of the previous tense.

Keywords: verb, tense, voice, mood, form, meaning, Azerbaijanian language, Japanese language, comparison, morphological indications, a sentence, a text

\section{Introduction}

Comparative study of language objects is a characteristic feature of modern linguistic investigation. At mutual correlation and confrontation of language units, forms, categories and so on, their specific peculiarities are exactly discovered. Determination of identical (integrative) and differentiated (differential) features of modern factors of the language is the main principle of linguistic comparison. By a result of structural-semantic comparison, elements of language system at any level-lexical, phonetic, morphological etc levels are distinguished. All rounded study of any language phenomenon directly suggests fixation in it different aspects, forms, meanings and other differences, (at complex identity of this phenomenon). On the other hand, the given language phenomenon should be included into different groups on the basis of a definite identity - formal, semantic, functional etc. identities.

Mentioned by us notes completely belong to the study of category of tenses of verbs. It is necessary to underline the fact that in the sphere of investigation of verbs, the necessity of carrying out comparison within one language is more than in other levels of a language.

As a principle, all the comparison carried out within a language requires fulfillment of at least, the following main conditions: a) one should have a basis of comparison, i.e., definite principal identity on the ground of which, both more peculiar resemblances and differentiations of the compared objects are considered; $b$ ) one should apply the only theory, the only method, the only understanding and terminological apparatus at describing all the compared objects.

Relation to identity and differentiation is characteristic not only for all possible phenomena, existing in the systematic links within one language, but also it is characteristic for the analogical phenomena in different languages. The mechanisms of these relations within a language and between the languages have many resemblances in themselves.

In interlingual relation, units, forms, categories and so on, not completing one another and not consisting of any real, only functional system, as a whole, are compared. That's why at interlingual comparison the meaning of individually-taken facts of a language as a system cannot be explored or realized their grouping in a certain paradigmatic wholeness, which are realized in the process of communication. However generalization of language means, used in the given system, and combination of semantic categories, which regularly are expressed in the languages of different systems, make it possible to give typological characteristics of their structure, i.e. to show the common and specific features for each of their peculiarities in the compared languages.

In the methodological purposes, for example, at learning a foreign language, it is possible to explain the facts of the studying language, by the way of comparing with the native language. However, even in this case, we think, the leading method of learning must be analysis of language phenomena as a system, but is must not be a simple fixation of equivalents for the forms of the native language.

In the article attempts have been made to consider tenses of verbs in the Azerbaijanian and Japanese languages on the basis of their comparison.

\section{Research Methodology}

The article explores study of languages completely different from each other. The Azerbaijani and Japanese languages which have been subjected for the investigation, belong absolutely to different language family groups and without their comparison it is impossible to discover their self-belonging peculiarities. Aimed at the investigation of absolutely different from each other (Azerbaijani and Japanese) languages, we have used comparative typological method of investigation.

\section{Scope of the Study}

Tenses of verbs function in the language not as something apart from one another occurrences, but they appear to be as a definite system. System of tenses of verbs is the whole of a number of tense forms compared with one another (Kholodovich, 1960). In each line appear all the forms of one tense. Any of forms of one row of tenses at a certain degree is similar as to the features, differing it from the other forms of the same or the forms of other line of tenses, compared as to the tense forms. Systematization, which is characteristic to the tenses of verbs, urges us to study them, taking into consideration the character of all the systems of tenses of the given language, discovering concrete rules of using each tense, different from the other. Comparison of investigation of systems 
of tenses of verbs is of great importance, because verbs are not only the main elements in the language system, but also they play a great role in the communicative process.

At comparative analysis of the materials of the two languages of different systems, it is not sufficient enough using their confrontation in the narrow sense of the word, i.e., confrontation of one element with the other. In order to take into consideration the place of compared elements of the two languages in the system of each of these languages confrontation of the studied languages in the widest sense of word should be carried out.

Often grammatical facts, seemingly being similar in the both languages as to their main features, do not resemble fully one another, for alongside them in each of these languages stand occurrence being together with the studied grammatical construction or with the form in the system relations. At the first view, this condition makes it difficult to carry out, comparative analysis of the languages, but in reality it enriches linguistic investigations and gives it determination and power, because it compels us to take resemblances and distinctions in their complicated interweaving and mutually dependence into consideration.

Study of this or that unit of a language can't be limited only with form, it must help us to explain the meaning of the studied form as well, and it is impossible without the analysis of their functions, which are closely related to the place, occupied by the given form, in the grammatical constructions.

\section{Study of Tenses of Verbs in the Azerbaijanian Language}

In the Azerbaijani language there are three tenses of verbs: past, present and future tenses. Category of tense of verbs appears from the correlation of past and future tenses with the present tense. For the expression of such correlation there exist morphological indications, which are called affixes. Budagova writes that "in the Azerbaijani language category of tense of verbs and voice are organically linked with each other, and many voice meanings are conveyed through tense forms" (Budagova, 1987).

Formal expression of grammatical tenses, we think, are realized only in the declarative mood where there are special formats for the expression of the past tense $(-d l /-d i /-d u / /-d \ddot{u} ;-m ı s ̧ / /-m i s ̧ / /-m u s ̧ / /-m \ddot{u} s)$ the present tense format $(-\imath r / /-i r / /-u r / /-u r r)$ and the future tense formats (-ar//-ar//-acaq//-acək). The rest of the moods of verb, i.e. indirect (conditional wish, obligation and mood of necessity) are neutral in relation to grammatical tenses. In these forms general tense meanings are implied deriving from the semantics of self form of this or that mood. So, the meaning of general future tense lies in the semantics of its conditionality, wish, obligation, imperativeness and necessity. While taking away this or that mood from the surface of the past tense in the language different morphological and syntactic means are used (presence of conditional words, links, auxilary verbs, special type of subordinate clauses and so on) and even in this case the past tense is not concreticized with the determination which is characteristic to the declarative mood.

The issue of mood is closely connected with the issue of modality in the language. Category of mood acts in many of the languages in the quality of grammaticalized forms of expressing modality, as it possesses the system of proper features, expressing the meaning of this or that shade of modal meaning. Vinogradov particularly noted: "Any whole expression of thoughts, feelings or excitement acts... in the form of a sentence..." which "simultaneously reflects reality and attitude of the speaker to this reality, which appears just in the catogory of modality" (Vinogradov, 1975).

Correlation between speech and reality, fixed by the view point of the speaker, character of subjective-predicative links, determined by the speaking person as true, real, wished, necessary, possible and so on, - all these attitudes can be expressed in the azerbaijani language by the help of definite affixes, characterizing this or that mood. For example: O bu gun işa getmolidir - "He must go to work to day" (obligation, necessity): Ona de bura galsin - "Tell him to come here" (motive): Kitabı oxusan yaxşı olar - "It will be better, if you read the book" (condition); Istryirzm bu gün kinoya gedim - "I want to go to cinema today" (wish).

In all the complex of means of expression of modality in the azerbaijani language more leading and determining role play the forms of mood of the verbs, as any sentence, as a rule, is formed in a modal plan, by the help of this or that form of verbs.

In the system of verbs in the Azerbaijani language, category of tenses and mood form unseperable unity and express various attitudes to the actions of reality, nevertheless they cardinally differ from one another.

Mood is a grammatical category, which designates attitude of the action to reality, expablished by the person who is speaking, but the category of tense indicates the attitude to the action or condition by the moment of speech. 
Category of tense of the verbs alongside the category of mood and person acts in the quiality of one of the main features of the sentence - predicativity. However verbs with the affixes of tense forms and mood in themselves, in majority of cases do not establish completion of sentences yet, predicativity in two compositional sentences is formed on the account of personal affixes. Changes as to the persons are characteristic for any predicate, not depending on the part of speech it is expressed, and is common for any part of speech. Just for this reason affixes can be considered as being common predicativity, but affixes of tenses and mood-as specific indications, belonging only to the verb (Guseynzadeh, 1968). That's why, considering them in mutual correlation and mutual conditionality helps us more exactly to explain the essence of category of tenses.

In the azerbaijani language past tense is distinguished by the variety of forms, expressing various colourings of actions: finished or unfinished, length of time, actions happening once or many times, categoric or in directness of actions and are devided into simple or complex (compositional) forms (Budagova, 1987).

Two types of simple form of the past tense is indicated:

1. Past categories tense. It is formed by adding four variant affix - $d l / /-d i / /-d / /-d \ddot{u} / /$ to the root of the verbs and personal affixes: yazdlm "I wrote", yazdin "you wrote", yazdl "he wrote", yazdlq "we wrote", yazdinlz "you wrote", yazdllar "they wrote".

The grammatical meaning of this tense lies in the fact that it designates a certain concrete objective action: Nahayat eva yetişdim (M.İbrahimov) - "At last I reached home".

2. Past narrative tense (perfect tense). In the modern Azerbaijani language there are three morphological indications -muş (with the phonetic versions -miş//-muş//-müss) $-\imath b$ (with phonetic versions $-i b / /-u b / /-u ̈ b$ ). Both affixes establish one and the same category of tense and differ from each other only formally. Conjugation of verbs in the perfect tense form takes place by means of conjoining the personal affixes to the root of the verbs: yazmıssan (yazmisan), yazıbsan "you have already written", yazıblar "they have already written", yazı "he/she has already written".

Grammatical meaning of the past narrative tense lies in the fact that it expresses the past fact of action in the present tense as a result of completed action.

Complex (compositional) forms are formed by the help of affixes idi and imiş: yazacaq idi//yazacaqde "he was going to write", yazacaq imiş//yazacaqmış "He seemed to have written".

In the Azerbaijani language present tense has got two forms: The first of which bears the name of present, but the second one is named present durational (continuous) tense.

1. Present tense is formed by means of adding affixes - $-\imath r / /$-ir//-ur//-ür to the root of the verbs, but the personal forms are formed by means of joining them personal affixes. This tense form designates actions to be completed at the moment of speech: yazıram "I am writing", yazırsan "you are writing", yazır "He/she is writing", yazırıq "we are writing", yazırsinız "you are writing", yazırlar "they are writing".

2. Present durational (continuous) tense (Guseynova, 2005) expresses action which has taken place before but is continuing at the moment of speech: yazmaqdadrr "He/she has been writing (the action is in the process).

In the Azerbaijani language future tense has two forms:

1. Categorical future (completion of action is an immutable fact) is formed by adding affixes -acaq//-acək and then affixes of persons are added: oxuyacağam "I shall read", oxuyacaqsan "you will read", oxuyacaqdir "he/she will read".

2. Uncategorial future is formed by means of adding affix -ar//-ar to the root of the verb, and they are joined suffixes of person: yazaram "I shall (perhaps) write", yazarsan "you will (perhaps) write", yazar "he/she will (perhaps) write".

Notion of tense is present in all the forms of verbs, even in the imperative mood, with the exception of indefinite forms. "Category of tenses of verbs is expressed by the historically stable indications appearing in conformity with the objective laws of the Azerbaijani language" (Fakhraddin, 2010).

\section{Study of Tenses of Verbs in the Japanese Language}

In the Japanese language grammatical tense is characterized by the opposition of two tense plans: 1) Present-future (not the past) and 2) Past tense. Such a confrontation is observed in indicative and presumptive of verbs (also in adjective in the predicative form and connection) in the finite form and simultaneously in the determining position. These two tense meanings are expressed by the proper affixes, united in one line of commonness of tense function. In the indicative form the endings of present-future tenses are $-る /-(r) \boldsymbol{u}$ and the ending in the past tense is -た/-だ/-いた - - ta/-da/-ita (Alpatov, 2008). 
Verbs in the form of $-る /-(r) \boldsymbol{u}$ which indicates present-future tense of not durable type of tense, all together expresses permanent and continuous actions, including the all time actions, giving the object characteristics, pointing to it to have the ability to do this action. Just the same form accompanies the verbs expressing the future tense. Present and future tenses are understood as the only plan: their differentiation is realized lexically and compositionally. For example:

1) 地球は太陽の周囲を回転する。Chikyuu wa taiyou no shuui o kaitensuru. - “The Earth moves around the Sun".

2) 今日も雨が降る。Kyou mo ame ga furu. - “And to day it will rain”.

3）市川さんは日曜の午後釣りに行く。İchikawa san wa nichiyou no gogo tsuri ni iku. - "Mr. Ichikava afternoon on Sunday will go fishing".

Verbs in the form of - $た$ /-ta which is the form of the past tense of not continuous type of tense, expresses actions to be completed at the moment of speech. Besides this form may have perfective shade of meaning. For example:

1) 訪問団は出発した。Houmondan wa shuppatsushita. - "Delegation has left”.

2) 雨がまた降り出した。Ame ga mata furidashita. - “Again it rained”.

Each of the actions, which takes place not at the moment of speech may show itself in double form: as not actual for the moment of speech, or as actual in a certain relation for this moment of speech. But the action which takes place not at the moment of speech, may be either in the past, or in the future tenses. From here derives the theoretical possibility of non-actual past tense, actual past tense, non-actual future tense and actual future tenses. Actual for the present tense is action or state. But not in all the cases we can speak of the actuality of the consequences of actions at the moment of speech.

In the modern Japanese language the tense of the final verb is determined by the orientation to two points of counting out: either at the moment of speech (but in the written variant at the moment of writing) or to the time of another event. Usage of the first point of counting gives relative time of the first order (or, otherwise absolute time), usage of the second point of counting gives relative time of the second order (or, otherwise, realize time in the narrow sense of this word). That's why system of tenses in the modern Japanese language is neither purely absolute, nor purely relative, but it is absolute-relative (Kholodovich, 1960). This absolute-relative system (if we take only the final forms) is not formal, but it is functional, because one and the same final form functions now absolutely, and now relatively. These functions (absolute and relative) are distributed, namely they are determined by the position of the verb.

Golovnin also considers that the final forms of the verbs, expressing the meaning of absolute time "in certain positions and in contexts acquire relative-time meaning" (Golovnin, 1986).

As to the opinion of Syromyatnikov (1971) in the Japanese language there is no absolute tense, but there is only relative tense. In the Japanese language the category of tenses is closely connected with the category of voice, particularly, form relation with -る- $-(\boldsymbol{r}) \boldsymbol{u}$ in the sphere of present or in the sphere of future depends on voice meanings.

Problem of voice-tense system of verb in the Japanese language is one of the debatable questions in the Japanese linguistics and arises interest in different aspects. So, Kudo Mayumi considering the modern concept of tenses of final forms of verbs differentiates two types of meanings of these forms: 1) the main meanings and 2) accessory meanings while saying this, he notes that in the modern Japanese language there are two tenses of verbs-past tense and non-past tense (present-future tenses) (Mayumi, 1995).

Verbs in the form of -る- - $(\boldsymbol{r}) \boldsymbol{u}$ and in the form of -た/-ta can be used in figurative meaning for the expressive aims, for the stylistic colouring of the text:

東京の何十万の家は一度に振動した。瓦が落ちる。空ガラスが飛ぶ。石垣が崩れる。Toukyou no nan juu man no ie wa ichido ni shindou shita. Kawara ga ochiru. Madogarasu ga tobu. İshigaki ga kuzureru. "Some ten thousands of houses in Tokio simultaneously begin to swing. Tiling falls down. Window glasses fly away. Stone walls break down" (Suzuki).

In this text the first sentence has the verbal predicate in the form of - た/ - ta expressing general tense plan of the past. The following sentence with the verb in the form of $-る /-(r) \boldsymbol{u}$ introduces the occurrances of the past as occurances taking place in the present tense. 
Tense forms, having relative (or correlative) meaning in the direct opposition (or absolute meaning), expresses time not related to the moment of speech, but it gives objective tense connection of the process, which is spoken about, with another process. They show that the process, expressed by the verb, took place (is taking place or will take place) either simultaneously with the mentioned process, either till that process or after it. That's why without paying attention to the relative tenses, it is too difficult to explain the usage of form of non-past tense in the narrative texts, which often takes place in the Japanese language (Bass, 2008). As to the observations of Syromyatnikov, in a number of novels written by Akutagawa quantity of form of "past tense" approximately is twice less than in the Russian literary translation of the same novel (Syromyatnikov, 1971). This witnesses of the fact that grammatical meaning of the form of verb must be determined particularly for the each language.

It is necessary to underline the fact that "great number of the form of the non-previous tense is not the result of their usage in the quality of so-called historical present tense at all: all of them point to the processes taking place simultaneously with the following one which is mentioned" (Syromyatnikov, 1971). But not all the actions, which precede the following mentioned ones are designated by the forms of - $t /-t a$. Consequently, in the given case we speak of the relativity of the tense. Verb forms of non-past tense can point not only to simultaneousness of the action, but also to the following one. Let's consider such an example:

布団に入って、目瞑ったが、眠れなかった。披露宴であの従兄弟と言う人がが小声で教えてくれた。 須黒医師の事を考え続けた。雨が屋根を吒く音が聞こえる。宿屋の遠くで暇な女中達が笑い声をたて ている。Futon ni haitte me o tsubutta ga, nemurenakatta. Hirouen de ano itoko to yuu hito ga kogoe de oshiete kureta. Suguro ishi no koto o kangaetsuzuketa. Ame ga yane o tataku oto ga kikoeru. Yadoya no tooku de himana jochuu tachi ga waraigoe o tatete iru (Y.Uno) - "I lay down to sleep, closed my eyes, but I could not fall asleep. I went on thinking about doctor Suguro, about whom cousin (of my husband) spoke to me in the wedding party in a low voice. Noise of dropping rain is heard on the roof. By the end of the drawing room the house maids, having finished their work, laugh".

In this text-narration verb forms of past and non-past tenses are related to each-other in such a manner that the given forms witness of the alternation of action, unwinding occurances in the only thematic plan as to the time.

Forms of tenses of verbs carry out substantially different functions depending on the function, in which type of texts they are used. Kholodovich notes that "in the modern Japanese language all the actions and states, expressed by the verb-predicate are not related to one another but they are related to one another from the moment of speech (and more widely from the moment of cognition) which just determines the time of each verb-predicative. All the actions and states are equalized as to the relation to this moment. This is the main law of choice of time in the text, consisting of a number of independent sentences" (Kholodovich, 1960).

If the designated situation in the sentence follow the situation to be designated in the following sentence, then the verb form of non-past tense is used:

横浜まで来て、二人は郊外電車に乗り換えた。電車は段々町を離れていく。Yokohama made kite, futari wa kougaidensha ni norikaeta. Densha wa dandan machi o hanarete iku. - Having arrived in Yokahama, both changed their trains to electric train. Electric train gradually moved from the town (Ichikawa).

Usage of tense forms in the presumptive verb is determined by the given rules:

1.それがさっきの男とは気づかないだろう。ぎんぺの方は二人を見ないではいられなかった。

Sore ga sakki no otoko to wa kizukanai darou. Gimpei no ho: wa futari o minaide wa irarenakatta. - "She could hardly notice, that it was the man, he (had) met before. A.Gimpay could not help looking at both of them".

2. そしてぎんぺい追跡したものがあろうとすれば、それはぎんぺいのしょじする 金だったろうか。

Soshite Gimpei o tsuiseki shite kita mono ga aru to sureba, sore wa Gimpei no shojisuru kane dattarouka. "If something pursued Gimpey, then it was perhaps money, which Gimpey happened to have" (Natsume).

Verbs in the indicative form express the meaning of relative time, if these forms occupy a definite position. Forms on not past tense witness of simultaneousness or systematization of actions related to the action of the main predicate, without depending on their relation to the moment of speech. For example:

タクシーが走っている道は昔の中仙道で。Takushii ga hashitte iru michi wa, mukashi no Nakasendou de. - "The way through which the taxi rode off, in the ancient times was a Nakasen track" (Ogawa).

If in a certain position forms of the past tense are used, then the dependent situation precedes the main, in this case absolute time can be any of them.

In all the cases, the tense which is designated in the subordinate clause, must be finished till the beginning of the situation designated in the main clause. At this time the second situation can directly follow the first one: 
そしてぎんぺいは事実殴られたショックを感じた。Soshite Gimpei wa jijitsu nagurareta shokku o kanjita. - "Then Gimpey felt shocked (from the thing that he was) really he was struck" (Natsume).

Also time interval is possible between the situations.

彼は大人になるまで自分の父親を知らないでいた。Kare wa otona ni naru made jibun no chichioya o shiranaide ita. - "He did not know his father, before he became grown up" (Endo).

In the Japanese linguistics the possibility of relative time (taxis) meaning is observed not only in the subordinate clause, but also it is observed in the principle clause. In the case of presence of adverbial manner of time in the subordinate clause, the usage of tenses may turn to absolute form from the relative one (Bondarko, 1987).

Let's compare the next example, where despite the meaning of taxis preceding in the subordinate clause it is impossible to use the form of the past tense.

明日いらっしゃる/らっしやった田村先生に水曜日にお会いします。Ashita irassharu / irasshatta Tamura sensei ni suiyoubi ni oai shimasu. - "On Wednesday I'll meet professor Tamura, who is coming tomorrow".

Verb in the form of the past tense ending in -た/-ta mainly expresses the action completed till the moment of speech: Sensei, kakimashita. - "The teacher wrote".

Verb in the form with ending -た/-ta can express special meaning of the past tense, when the expected event is taking place.

Past tense here shows, that the speaker found out or remembered, that is, the given occurance is expected. In such cases -た/-ta enters the composition of verbs of everyday use. For example オヤ、ここに銭があった。Oya, koko ni sen ga atta. "Oh, here is the coin!" (the person looked for the coin and at last found it).

Different view points exist on the verb -た/-ta in such constructions. So, the meaning of finding out and remembering given by the form - た/-ta is considered by A.Mikami as two different meanings (Hideo, 1984). As to the view of A.Mikami, in such cases form of verb of the past tense with - た/-ta can be changed with the form of the non-past tense with - う/- $\boldsymbol{u}$ (Akira, 1987).

In the Japanese language, besides the forms of past tense and non-past tense, there are also voice-tense forms with -ている/-te iru (present time) and -いた /-ita (past time). These voice forms mainly express the meaning of duration (continuous) in the past:

長い美しい帯を締めいている。Nagai utsukushii obi o shimete iru. - "Nagai wears long nice belt" (S.Endo); あなたはいつでも私に力を与えてくださいましたわ。Anata wa itsudemo watashi ni chikara o ataete kudasaimashita wa. - "You always gave me power" (Suzuki).

The given voice-tense forms possess and also such meanings as perfectness-ている/-te iru and pluskvamperfectness -ていた/-te ita.

The ability of the form with -ている/-te iru for giving perfect shades of meaning derives from tense meanings, composing its components. Syromyatnikov writes: "When the form with -ている/-te iru expresses earlier action, the result of which is being kept and at the next mentioning of the action, the meaning of this form appears to be simply sum of meanings composing its form: form with - $/$-te designates the previous action, form with - う I- $\boldsymbol{u}$ from the verb of everyday use designates result, to be kept in the period of the next action to be mentioned" (Syromyatnikov, 1971).

すると、突然照子は袖を落として、涙に濡れている顔をあげた。Suruto totsuzen Teruko wa sode o otoshite, namida ni nurete iru kao o ageta. - "Then Teruko suddenly let his hands go down and raised his face pouring down with tears" (Akutagawa).

It is necessary to note that the verb tense with the form -ている/-te iru "may give the meaning of both durable and permanent, many a time repeated actions.

燕は春、日本にやって来る。Tsubame wa haru Nihon ni yatte kuru. - "Swallows fly back to Japan in spring" (Suzuki).

Verbs with the form -ていた/-te ita despite the fact that mainly designate durable (long) process in the past, but the given form also can express:

1) pluskvamperfect meaning: あの時もうお姉さまは、わたくしがしゅんさんに差し上げるはずの手紙を 読んでいらしったのですよ。Ano toki mou oneesama wa, watakushi ga Shunsan ni sashiageru hazu no 
tegami o yonde irashitta no deshou. - "Sister then already might have read the letter, which she just wanted to give back to Syun" (Akutagawa).

2) The meaning of repetition: 僕たちが子供の頃は、学校へはみんな 歩いていた。Bokutachi ga kodomo no koro wa, gakkou e wa minna aruite ita - "In childhood we all used to walk to school".

3) Verification of facts 昔、この辺りには川が流れていた。Mukashi, kono atari ni wa kawa ga nagarete ita. - "In ancient times in this province a river ran" (Toshinge).

Observations on the Japanese language show that, different forms can belong to one and the same grammatical tense, as almost in the quality of synonymity. These different forms can also belong to different mood and voice of the verbs. Nevertheless, one should not consider that tense meaning of the verb form is determined by the syntactic position in the structure of a sentence or a text. Syntactic position of verbal lexeme influences on the choice of forms of the tenses. But the meaning of the forms of the tenses remains mainly as one and the same in any syntactical position.

\section{Comparative Study of Tense Forms in the Azerbaijani and Japanese Languages}

Investigation of tense forms in the Azerbaijani and Japanese languages on the basis of their comparison suggests first of all, analysis of structural semantic and functional pecularities of the verbs. It was mentioned above, that in the voice-tense system of verbs in the Japanese language are established on the basis of two tenses - non-past tense (form with - う/- $\boldsymbol{u}$ ) and the form of the past tense (form with -た/-ta) and also form of durable (long type) (ている/-ていた/-te iru/-te ita). Voice-tense system of verbs in the Azerbaijani language differs by the fact that it is characterized by nine-member tense oppositions. That's why the meaning of this or that form of the tenses of verbs in the Japanese language can be expressed in the Azerbaijani language by different means.

Thus, the meaning of verb form with $-\zeta /-\boldsymbol{u}$ is similar with the verb forms of the present tense in the Azerbaijani language which are formed by the help of suffixes - $-\imath r / /-i r / /-u r / /-u r r$ and expresses permanent or repeated actions. For example:

1. 主人は毎日学校へ行く。Shujin wa mainichi gakkou e iku. Ağa hər gün məktəbə gedir. "Master goes to school every day" (Akutagawa).

2. 本条約は双方の標準後直ちに発効する。Hon jouyaku wa souhou no hyoujungo tadachini hakkou suru. Bu müqavilə hər iki tərəfin ratifikasiyasından dərhal sonra qüvvəyə minir (minər). "The real treaty is valid soon after it is ratified by the both parties" (Natsume).

If an action is taking place at the moment of speech, then in the Japanese language it is expressed by the verb form - う/-u, but in the Azerbaijanian language it is expressed by the verb forms with suffixes - $-r / /$ ir//-ur//-ür.

私はてるさんさえ幸福なら、なんより有難いと思っているの。本当よ。しゅんさんが瑛さんを愛して いてくれれば。Watashiwa Terusan sae koufuku nara, nanyori arigatai to omotte iru no. Hontou yo. Shunsan-ga Terusan-o aishite ite kurereba.... Ogər Teru xoşbəxtdirsə, bu məni hər şeydən çox sevindirir. Doğrudur! Đgər Syun Terunu sevirsə... "And if Tery is happy, I am glad most of all. It's true! If Sym Loves Tery..." (Akutagawa).

In the Japanese language verb form of the non-past tense with the ending - う/- $\boldsymbol{u}$ depending on the context expresses also future tense. In the Azerbaijani language two forms of the future tense are functioning: the form of categorical future with the suffices $-a c a q / /-\partial c \partial k$ and non-categorical form of future with the suffixes -ar//-ər. If taking place of the action is inevitable, then the categoric form of the future tense is used; but, if taking place of the action is supposed, then non-categoric form of the future tense is used.

If taking place of future tense is inevitable then, in the Azerbaijani language the usage of the verb form of present tense instead of future tense is a norm:

Oyləşin, kitabı dostuma verib qayıdıram. - "Sit down, I'll give the book to my friend and come back".

If in the Japanese language supposition of the future action can be given by the form of suppositional mood with the ending 一おう;ーよう/-ou; -you, but in the Azerbaijani language it is expressed by the form of the categorical future tense, ending in the suffixes -ar//-ər. For example:

1. 来月は菊の花が咲こう。Raygetsu wa kiku no hana ga sakou. Gələn ay, görünür, xrizantemalar çiçəkləyər. - "Next month, chrysanthemum may flourish" (Natsume).

2. そんなことを言うと人に誤解されよ。Sonna koto o iu to hito ni gokaisareyo. Ogər bunu desək, adamlar, ola bilsin, başa düşməz. - "If we tell this, then the people may not understand" (Ichikawa). 
Usually it is considered that the form -おう; -よう/-ou; - you is the sign of non-categorical, or suppositional, future tense, because, form $-\zeta /-\boldsymbol{u}$ is exactly categorical, then the problem of confrontation of future tense with the -おう; 一よ/-ou, - $\boldsymbol{y o u}$ and future tense with the form -う/-u bring to the contrasting of categorical and non-categorical modality-う/-u: if おう; -よう/-ou, -you means “will fly, flies" then the form 飛ぶ/tobu gives the meaning of 飛ぼう/tobou "perhaps it will fly, will fly".

However, this question remains debatable. For example, I. V. Golovnin denies the presence of special future tense in the Japanese language, joining those grammarians, who consider that difference between the grammatical meanings of the forms with the endings -う/- $\boldsymbol{u}$ and -おう; -よう/-ou, -you lies in their modality which is not the same for both, particularly in their belonging to different moods (Golovnin, 1986).

Verb forms of non-past (present and future tenses) tense with the suffix —う/- $\boldsymbol{u}$ in the Japanese language and the present tense ending in suffix - $-r / /-i r / /-u r / /-u ̈ r$ in the Azerbaijani language are characterized by the fact that these forms are used stylistically for more lively action in the past:

1. 頭も体も真は疲れていながら、なかなか眠ることが出来なかった。 Atama mo, karada mo shin wa tsukarete inagara, nakanaka nemuru koto ga dekinakatta. Baş və bədən həddən artıq yorulmuşdu, lakin o heç cür yuxuya geda bilmirdi. - "Both the head and body were too tired, but he could hardly sleep" (Shimazaki).

2. 私は度肝を抜かれて、泣くことも出来なかった。Watashi wa dogimo o nukarete, naku koto mo dekinakatta. Qorxmuşkən mən hətta ağlaya bilmirdim. - "Being frightened I couldn’t even cry" (Shiga).

It is necessary to note that such features of verb forms of non-past tense ending in the suffix $ー う /-\mathbf{u}$ in the Japanese language, as the expression of the meaning of indirect order, request etc. are characteristic. In the Azerbaijani language the meaning of order, request etc. are expressed by the imperative mood or by the categoric past tense. In such cases grammatical construction acquires special expressive power:

泣くな、もう泣くな。Nakuna, mou nakuna. Ağlama, day ağlama. - “Don’t cry, don’t cry any more!”

馬鹿を言うなよ。Baka o iuna yo. Boş-boş danışma. - "Don’t say nonsense”.

心配するな。Shimpaisuruna. Narahat olma. - “Don’t bother”.

Verb form of the past tense ending in the suffix —た/-ta mainly expresses the action completed till the moment of speech. In the Azerbaijani language this meaning is expressed by the form of the past categorical tense, ending in suffixes $-d l / /-d i / /-d u / /-d \ddot{u}$ :

所々丹塗りの剥げた大きな丸柱。Tokorodokoro ninuri no hageta, ookina marubashira. Böyük dairəvi sütunların bəzi yerlərindən qırmızı boya qopmuşdur. - "Big round columns from which in some places red varnish was peeled off' (Akutagawa).

For the verb form ending in the suffix -た/-ta in the Japanese language is the fact that it expresses repeated action in the past. In the Azerbaijani language the meaning of repeated action in the past is expressed by the definite imperfect:

家の人はみんな留守で、お婆さんだけが、日当たりの良い縁側で継ぎ物をしていらっしゃいました。Uchi no hito wa minna rusu de, obaasan dake ga, hiatari no yoi engawa de, tsugimono o shite irasshaimasita . Evdə heç kəs yox idi, yalnız nənə günəşli aynabənddə işlə məşğul idi. - "All the people in the house were absent, only granny in the sunny verendah was busy knitting" (Shiga).

Verb form ending in suffix -た/-ta can have perfect meaning as well, i.e. can express completed action, the result of which in the process of narration is directed to the acting of the following action. In the modern Japanese language there is not any perfect tense as a special form of verb tense. Nevertheless, the verbs forms with suffixes -た/-ta and -ている/-te iru shades of perfect meaning are characteristic. In the voice-tense system of the Azerbaijani language perfect functions as one of the main meanings of past declarative tenses and has the following morphological indications such as: -mış//-miş//-muş//-müs and -ıb//ib//-ub//-üb.

定まって、これはけわいしがかかりました。Sadamatte kore wa kewaishi ga kakarimashita... Bu asılmış, görünür, şerlər olan kitabdır... - "Perhaps it is paper with poems hanging there" (Kawabata).

The meaning of the verb form ending in suffix -ている/-te iru (present tense) and in suffix -ていた/-te ita (past tense) in the Japanese language and their equivalents in the Japanese language are of special interest. Let's consider them.

Verb forms in suffix -ている/-te iru (present tense) and -ていた/-te ita (past tense) in the Japanese language mainly express the meaning of durable (continuous) action. This meaning in the Azerbaijani language is expressed by the verb form of present tense ending in suffixes $-\imath r / /-i r / /-u r / /-\ddot{u} r$. For the plan of past tense here 
definite imperfect may take place as well. With the aim of expressing the meaning of duration (continuation) in the Azerbaijani language also forms of present and past continuous tenses can be used:

1. むしろ、一瞬の満足の上がしんごの心を軽くしている。Mushiro, isshun no manzoku no jou ga Shingo no kokoro o karuku shite iru. Bir qədər məmnunluq hissi Şinqonun ürəyini rahatlaşdırd. - "Feeling of some satisfaction eased Shingo's heart" (Ichikawa).

2. 月の良い晚でした。牛若丸が笛を吹きながら歩いていました。Tsuki no yoi ban deshita. Ushiwakamaru ga, fue o fukinagara aruite imashita. Gözəl aylı bir axşam idi. Uşivakamaru fleytada çalaraq gəzişirdi. - "It was a fine moon - lit night. Ushiwakamaru walked playing the flute" (Endo).

In the Japanese language perfect meaning of the verb forms with 一ている/-te iru in the Azerbaijani language are similar with past declarative tense, but pluskvamperfect meaning of the verb form 一ていた/-te ita coinsides the ancient past tense, i.e. the pluskvamperfect in the Azerbaijani language:

1. 僕は、急いで起きて、魚の鱗のこびり付いている服を着た。Boku wa, isoide okite, sakana no uroko no kobiritsuite iru fuku o kita. Mən tez qalxdım vo balıq pulcuqları yapışdırılmış xüsusi paltarı geyindim. - "I quickly got up, put on my special ware to which fish-scales were stuck" (Akutagawa).

2. 私はその時近くの森の中の歩道を歩いていたんですよ。Watashi wa sono toki, chikaku no mori no naka no hodou o aruite itan desu yo ( Mən həmin vaxt yaxınlıqdakı meşənin cığırı ilə gedirdim. - "By that time I was going along the path in the nearest forest" (Suzuki).

In the Japanese language forms of passive perfect with the suffix te aru and passive pluskvamperfect with -てあ った/-te atta are functioning. The meanings of these forms in the Azerbaijani language are expressed by passive voice of the past tense, and declarative and ancient past tenses:

1. ...色々な着物の古くなったのを使ってあるが、その中には、かつて私のものだった見覚えの確かに あるのもあるのであった。Iroirona kimono-no furuku natta no o tsukatte aru ga, sono naka ni wa, katsute watashi no mono-datta mioboe-no tashikani aru no mo aru no de atta. Mən gördüm ki, bələyin üzərində müxtəlif qədimi kimonolar istifadə olunub və onların arasında yaxşı xatılladığım mənimkilər də var idi. - "I saw that on the swaddling clothes different old kimonos were used, and among them were mines too, which I remembered quite well" (Shiga).

2.それから飯をすましてすぐ学校一出掛けた。靴は磨いてなかった。 Sorekara meshi o sumashite sugu gakkou e dekaketa. Kutsu wa migaite nakatta Səhər yeməyindən dərhal sonra mən məktəbə yollandım. Çəkmələr təmizlənməmişdi. - "Then I at once after breakfast I started to school My boots seemed to be dirty" (Natsume).

Verb forms ending in -ていた/-te ita can express the meaning of repetition as well. This meaning in the Azerbaijani language is realized by the help of definite or indefinite imperfect:

1. みんながワイワイ言うのを、はじめから黙って聞いていた一人の子 供がいました。Minna ga wai wai yuu no o, hajime kara damatte kiite ita hitori no kodomo ga imashita. Q1şqıran uşaqlar arasında əvvəldən sakitcə qulaq asan bir uşaq vardı. - "Among the crying children was one child, who from the very start silently listened" (Ogawa).

2.木こりが、池のそばの森で木を切っていました。斧に力を入れて、コンコンと聞いていました。

Kikori ga, ike no soba no mori de ki o kitte imashita. Ono ni chikara o irete, kon-kon to kiite imashita. Odun doğrayan meşəlikdə gölməçənin yanında ağac doğrayırdı. O, güclə doğrayırdı: tuk, tuk. - "Wood cutter hewed wood in the grove at the pond. He hewed using much power: tuk, tuk" (Kawabata).

\section{Conclusion}

Scientific investigation of category of tenses of verbs in the Azerbaijanian and Japanese languages makes it possible for us to come to the following conclusions:

1. Different moods and tenses of Japanese verbs not always exactly similar with the Azerbaijani verbs. General rule of relatively usage of present, past and future, keeping the pecularity of meaning for the last one, lies in the fact, that in the Japanese speech they consider more the moment, about which it is spoken, than the time when the speech follows. Present tense of the indicative mood, besides designation of reality, as it is in the Azerbaijanian language, as for example 出る-deru “I go out" expresses also some other tense meanings.

2. In the modern Japanese language a special means of expressing repeatedness of two carried out actions following each other take place: verb in the form with - $/$-te designating preceding action + singled out comparative particle --は/-wa + verb designating the following action, for example: 
我々三人は、それから良く集まっては相談した。Wareware sannin wa, sorekara yoku atsumatte wa soudanshita. Biz sonra tez-tez üçlükdə toplaşır və məsləhətləşirdik. - "Then we often used to gather in three and consulted with one another.

3. Verb, in the form of -ては/-te wa here is one of the homogeneous predicates and designates actions, which precede another actions of the same subject (the same group of subjects) and both of them take place repeatedly.

4. So, as it became obvious to us in the process of investigation that the structure of the Azerbaijani and Japanese languages greately differ from each-other as to the technigue of grammatical means, but as a whole in a number of cases they coinside as to the existing grammatical categories, self-belonging parts of speech and also as to the syntactical usage of these parts of speech.

However in the process of comparison of this or that tense form of verbs of the Azerbaijani and Japanese languages, it is discovered that the meanings of tense forms in the Japanese language are more conditioned by their contextual surrounding in the grammatical constructions.

In the Azerbaijani language these meanings are expressed mainly by the morphological indications of this or that tense form of verbs.

\section{References}

Akira, M. (1987). Gendai gohoo josetsu. Tokyo: Kuroshioshuppan.

Alpatov, V. M., Arcade, P. M., \& Podlesskikh, V. I. (2008). Theoretical grammar of the Japanese language. Natalis.

Bass, I. I. (2008). Problems of modern Japanese linguistics. Linguistics' text. Moscow.

Bondarko, A. (1987). General description of the semantic and structural theory of taxis. Functional Grammar: An Introduction.

Budagova, Z. I. (1987). Basics of grammar of modern Azerbaijani language. Morphology. Baku: Elm.

Fakhraddin, G. (2010). Category of time in Turkic languages. Baku: Nurlan,

Golovnin, I. V. (1986). Grammar of contemporary Japanese. Izd. University Press.

Guseynov, L. (2005). System of extended verb tenses. Baku.

Guseynzade, M. G. (1968). Categories of tense and mood of the verb in the modern Azerbaijani language. Questions of the categories of time and mood of the verb in the Turkic languages. Baku: Elm

Hideo, T. (1984). Syntax of Japanese II. Tokyo: Kuroshioshuppan.

Kholodovich, A. A. (1960). Time, type and aspect of contemporary Japanese. Ser. History, Language and Literary, 3(14).

Mayumi, K. (1995). Aspect, time and tense of text. Tokyo: Shohan.

Syromyatnikov, N. A. (1971). The system of tenses in the modern Japanese language. Nauka.

Vinogradov, V. V. (1975). On the category of modality and modal words in Russian. Research on Russian Grammar. Nauka.

\section{Copyrights}

Copyright for this article is retained by the author(s), with first publication rights granted to the journal.

This is an open-access article distributed under the terms and conditions of the Creative Commons Attribution license (http://creativecommons.org/licenses/by/3.0/). 